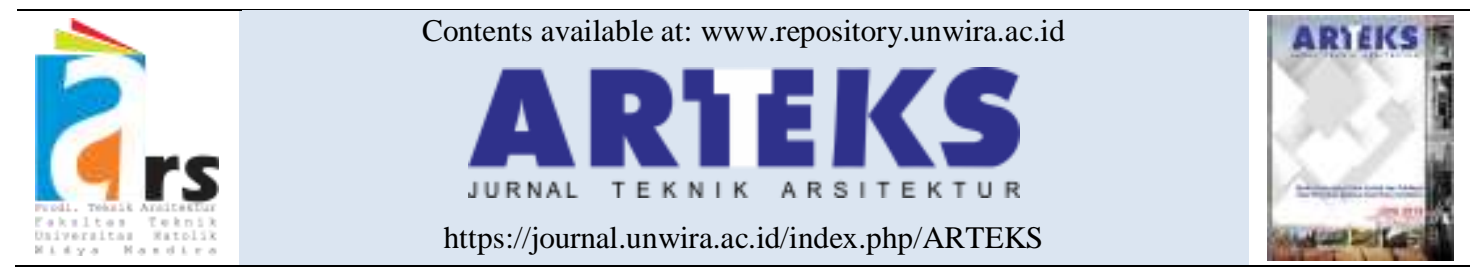

Research paper

doi: 10.30822/arteks.v6i3.999

\title{
The settlement concept of Dayak Kenyah community in the Budaya Pampang Village, Samarinda City
}

\author{
Puput Wahyu Budiman ${ }^{\circledR}$, Sudaryono* \\ Master in Urban and Regional Planning, Department of Architecture and Planning, \\ Faculty of Engineering, Universitas Gadjah Mada \\ Jl. Grafika, No. 2, Sekip, Yogyakarta, Indonesia
}

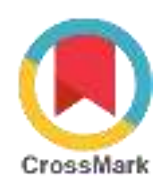

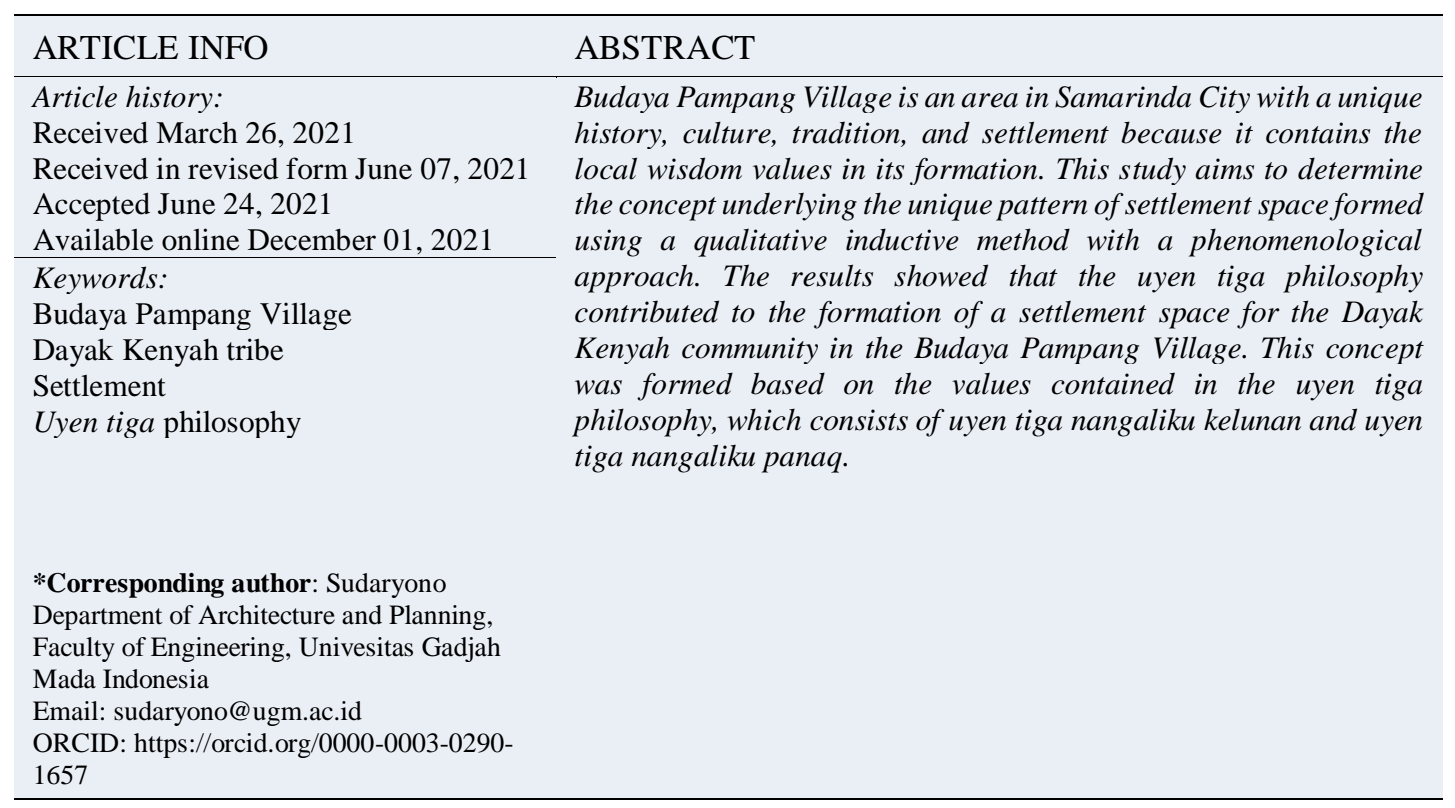

\section{Introduction}

Budaya Pampang is a traditional village with unique cultural attractions as its trademark (Sulisthio and Nurdiah 2013). Furthermore, traditional villages comprise tourism potentials in dances and outstanding natural scenery, including exotic housing and the inhabitants' way of life (Kumurur and Damayanti 2009). Cultural diversity is one of the factors that attract tourists. However, it is faced with the challenge of maintaining cultural values from external influences (Nilasari, Irianto Sitindjak, and Wardani 2019; Harefa 2019). In addition, the development of tourism in an indigenous community affects the spatial arrangement pattern (Wibawa, Samekto, and Gelgel 2019), which offers specific physical and non-physical characteristics (Agustian et al. 2020).

Generally, the Dayak people are mostly farmers and hunters (Singarimbun 1991). The Kenyah Dayak community in the Budaya Pampang Village originated from Apokayan. Compared with other Dayak tribes, they are territorial communities (Coomans 1987), especially in defending their game lands and farms. In the past, there were often violent disagreements between other Dayak tribes. The losers were forced to migrate to avoid prolonged conflicts. Apart from the struggle for land, economic factors are also part of the reason they tend to migrate. This further causes the community to adapt to their new environment and 
develop new habits that also affect their dwellings (Mazza and Punzo 2016).

The Dayak Kenyah community possesses local wisdom values, a characteristic of the Budaya Pampang Village. These form a new culture related to space and place (Tuan 1997) and influence the development of their residential environment (Sasongko 2005). Cultural influences are shown in the distinctive settlement arrangement patterns (Ari and Antariksa 2005). This is based on the values held by the community, especially beliefs. For example, in Bali, the philosophy of Hinduism serves as the basis for determining the spatial layout of settlement (Dwijendra 2008). In addition, the philosophy of Islam also affects settlement arrangement, thereby leading to the development of a unique pattern (Burhan, Antariksa, and Meidiana 2008).

The settlement (lepoq) of the Dayak Kenyah people has different characteristics related to their origin (Pergitawati, Antariksa, and Ridjal 2014). Differences in their living concept are influenced by various aspects such as geography (Wicaksono and Kusdiwanggo 2016) and the adopted local wisdom values (Adiputra et al. 2016). This cultural change in living is because culture and settlement are perceived as a unit (Sasongko 2005; Sastrosasmito 2020). Therefore, the new culture affects an existing settlement (lepoq) consisting of lamin adat and amin lu'ung and possesses unique shapes and patterns. This was built according to the prevailing tradition in the community, thereby indicating that socio-cultural factors influenced the settlement (Rapoport 1969). These factors offer values (Agustian et al. 2020) reflected in daily activities (Yusupova 2018), thereby leading to the uniqueness of the Dayak Kenyah settlement, which is interesting to study.

The grand and mini-tours (Hermanto, Djunaedi, and Sudaryono 2014) performed in the Budaya Pampang Village led to discovering several interesting phenomena, including the settlement pattern that tends to cluster around the lamin adat, and peacefully coexist alongside other tribes. Furthermore, the community dwellings are in the form of stilts built on sufficient land area. Furthermore, the farming methods are unique and environmentally friendly, and people stay away from waterfalls when building a shelter in the thick traditional settlement. This led to the following research question, namely, what concepts and values affect the Dayak Kenyah tribe in the Budaya Pampang Village. Therefore, this study aims to explore the concepts and local wisdom values that underlie the Dayak Kenyah tribal settlement formation, which also serves as input for the development of spatial planning in East Kalimantan Province.

\section{Method}

A qualitative inductive method and a phenomenological approach to determine the meaning of these values were adopted (Pahude, Sudaryono, and Kristiadi 2017). This is one of the ways to comprehensively understand the subjective experiences in a spatial phenomenon, such as behavior, motivation, action, adaptation, culture, belief, and others (Kahija 2017).

The grand tour is the initial stage of an inductive study to analyze problems and empirical phenomena (Sugiyono 2019). The data collection started with grand and mini-tours followed by indepth interviews with 9 informants from Budaya Pampang Village. The respondents or informants were selected using the purposive sampling technique, while in-depth interviews were conducted with the snowball technique (Sugiyono 2019). Data analysis was carried out by deepening the 14 information units obtained, which were categorized into 5 empirical themes, as well as investigating the substantial relationships between them. The 5 empirical themes were dialogued on in order to generate local theories regarding the concept of the Dayak Kenyah Tribe Community Settlement in the Budaya Pampang Village.

\section{Result and discussion}

The in-depth interviews with 9 informants, led to the realization of 14 information units with 5 empirical themes, which contributed to the formation of the Dayak Kenyah community settlement in the Budaya Pampang Village, are as follows.

The process of a settlement formation

This theme consists of 2 information units, including the origin and shift of livelihoods. The settlement formation process starts with the origin of the Dayak Kenyah community in the Budaya Pampang Village. They originated from 
Apokayan, Malinau Regency, North Kalimantan and have a similar border with the Malaysian State of Sarawak. This tribe migrated in 1960 in search of a better means of livelihood. Initially, the settlements in Apokayan, were in the form of umaq dadoq a communal house, however it was influenced by migration. During the early days of their arrival, the people lived in huts (lepou) arranged in a spreading pattern. This was because their main source of livelihood was hunting and farming, which caused the Dayak Kenyah people to live close to the fields and forests.

There were 6 clans that inhabited Pampang village at that time, namely lepoqtau, bakung, maqjanan, maqlasan, umaqbaqa, and lepoqbau. In those days, the Dayak Kenyah people lived in lepou and adopted a spreading pattern because there was lack of unity among the ethnic groups. Furthermore, there were often conflicts over hunting and farming land. This became alarming and led to frequent casualties. Village elders (tetuha) from each clan gathered and discussed ways to resolve this issue and ensured no member of the Dayak Kenyah tribe was harmed. A consensus was reached to build a lamin adat as a symbol of unity with the slogan pemung tawai (one mind one goal), which is based on the philosophy of uyen tiga nangaliku panaq (regulating relations among the Dayak Kenyah tribe).

The elders also issued advice and ensured cultural activities are centered on the lamin. This attracts both foreign and domestic tourists, therefore the main source of livelihood shifted from farming and hunting to tourism services. Although, these activities are also part of tourist attractions. Furthermore, the existence of lamin adat as the center of cultural activity and a means of tourism affected the settlement pattern.

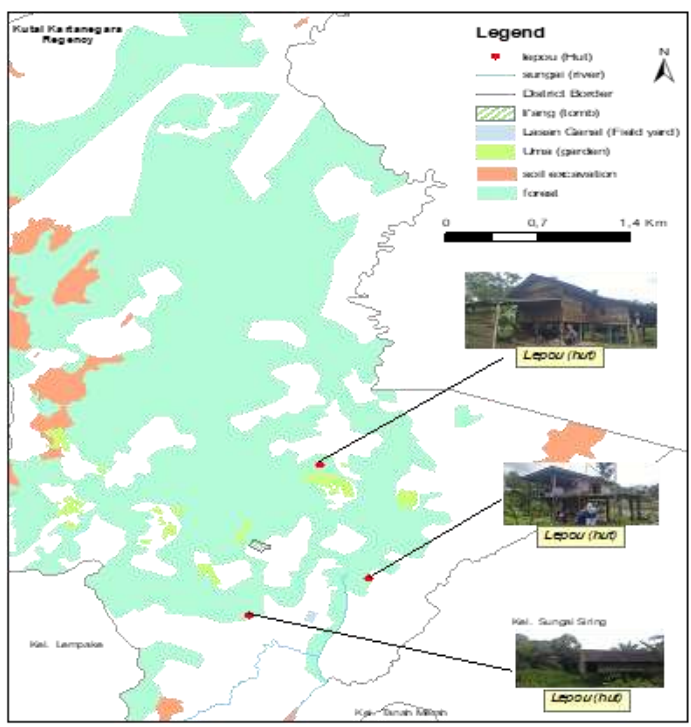

Figure 1. The initial settlement of the Kenyah Dayak tribe in the form of scattered lepou (huts)

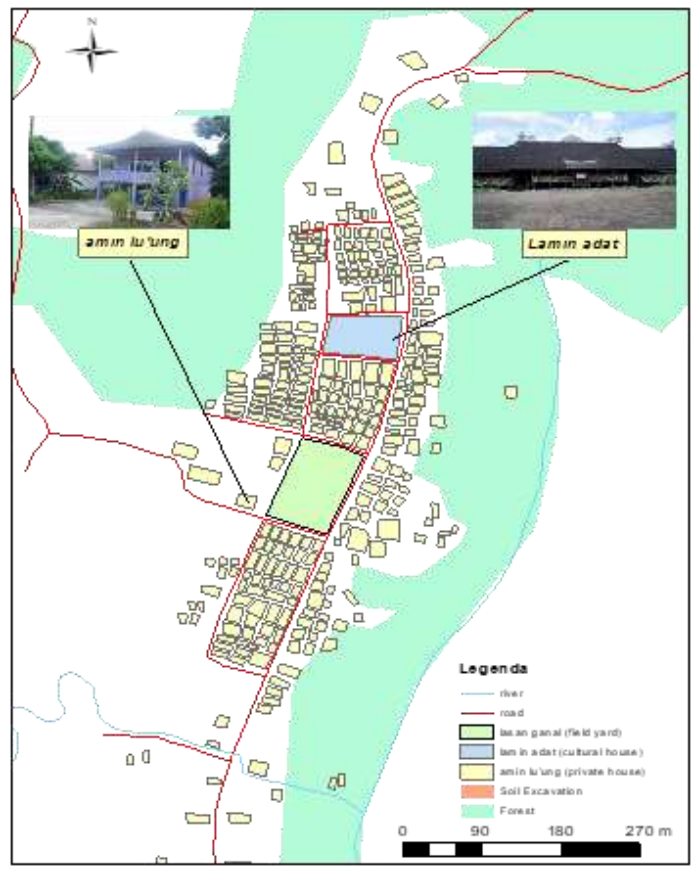

Figure 2. The current occupancy in a clumped pattern

Applicable customary law

This theme comprises 4 information units, namely the philosophy of uyen tiga (shared house), the motto of pebeka udip (living together), the prohibition of building shelter around waterfalls (u'ung), and the way of bahuma (farming) in gilir balik. The findings in the field show that the prevailing customary law affected the settlement pattern. In the Budaya Pampang 
Village, customary law is based on the uyen tiga (shared house), uyen tiga nangaliku kelunan (the relationship of the Dayak Kenyah people with other tribes, the creator and the natural environment) and the uyen tiga nangaliku panaq philosopies (the relationship between members of the Dayak Kenyah). These philosophies contain unwritten rules in the form of advice, prohibitions, slogans, rituals, and fines.

Some customary laws that serve as the basis for living in the Dayak Kenyah community are the motto of pebeka udip (living in unity). This teaches the people to live in unity with other ethnic groups because they constitute part of the uyen tiga concept (figure 3). However, when a conflict occurs, it is resolved immediately by ensuring both parties are fined in the form of a saber or mandau. The next customary law is the prohibition of building settlements near waterfalls (u'ung) because it is considered a sacred area. Therefore, a cultural space considered sacred need not be inhabited by the community, as shown in figure 4.

The way of farming (bahuma) in the Dayak Kenyah community has its uniqueness, besides a shifting or rotation method was adopted (gilir balik). There is a rule that every family head is not allowed to possess more than 5 plots of land. It is also recommended that a plot of land be cultivated yearly. It is hoped that the first plot needs to be recultivated in the sixth year, assuming it becomes fertile (figure 5). This rule is a kind of law and, when violated, the offender pays a fine in the form of traditional goods. Settlement establishment priorities farmlands (bahuma), thereby causing it to look compact.

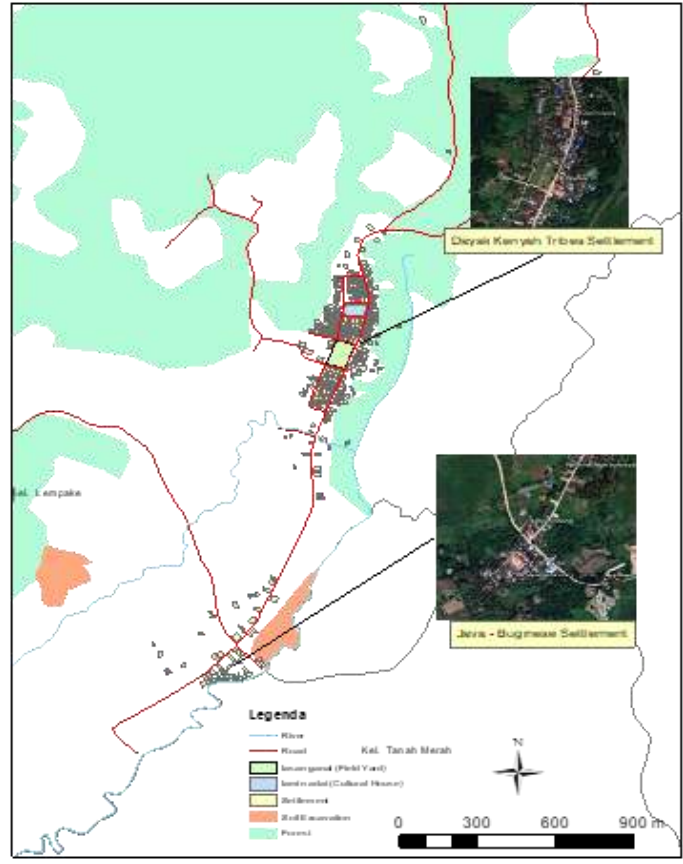

Figure 3. The motto of pebeka udip (living in unity) in settlement

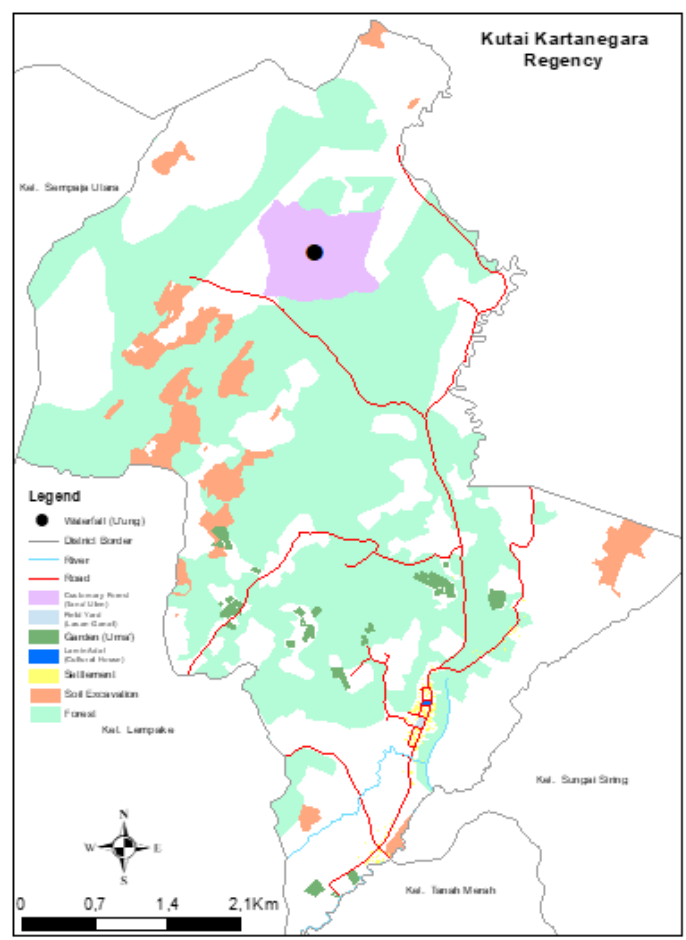

Figure 4. Prohibition of building settlement around u'ung (waterfall) 


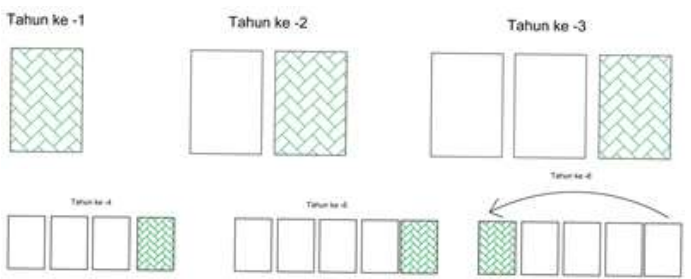

Figure 5. Illustration of the bahuma (farming) rules in a gilir balik

\section{Culture in settlement}

This theme consists of 1 information unit, namely socio-cultural activities in settlement. These activities generated certain patterns. This is a manifestation of the implementation of the uyen tiga philosophy which advocates respect for other residents, ethnic groups, the creator, fellow Dayak Kenyah tribes, and the surrounding environment. Furthermore, various socio-cultural activities create residential spaces as shown in the following figure.

The kahwin ritual is carried out during weddings and it consists of 3 stages, namely alaq leto (picking up the bride), pekatuq (giving advice) and reception. In the alaq leto stage, the spaces used are the groom's house (amin lu'ung), the street (janan), and the bride's home (amin lu'ung). During the pekatuq stage, the groom's house is used as the living room (dalem). However, for the reception stage, the rooms used are the groom's house (amin lu'ung), the street (janan), and the lamin adat. In simple terms, the room used for the marriage ritual stages are shown in figure 6.

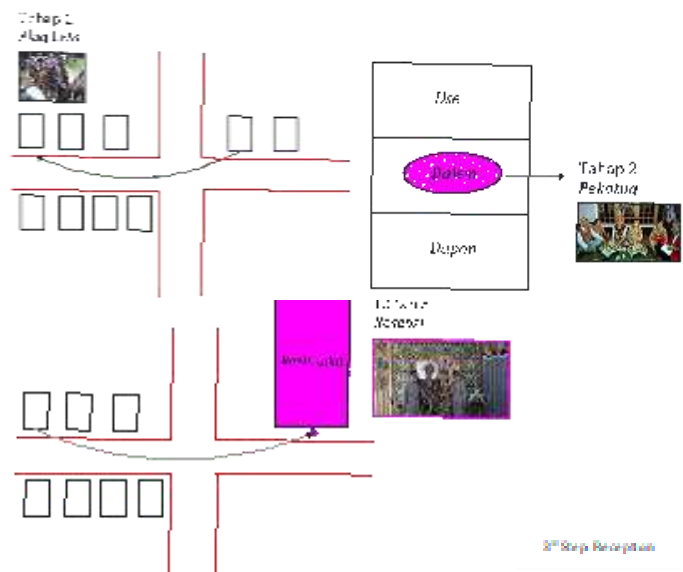

Figure 6. The use of space in the kahwin (marriage) ritual

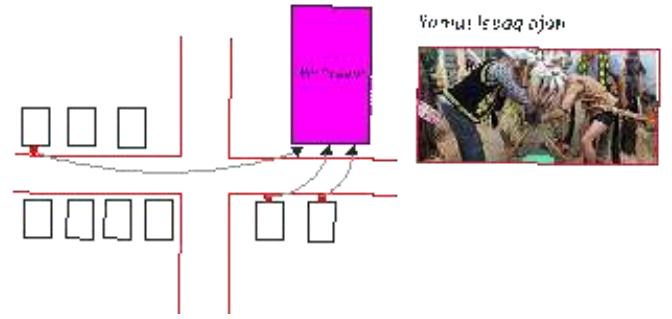

Figure 7. The use of space in ramai lepaq ajau activities

The birth of a Dayak Kenyah child in the Budaya Pampang Village was marked by the ngabayen uyen ngadananak ritual. This event usually takes place in amin lu'ung. The space used is the dapon (kitchen) where food for the consumption of thanksgiving events is prepared. In addition, core events occur in the dalem (family room) as shown in figure 8 .

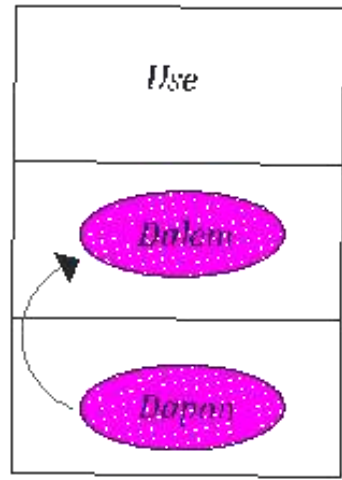

Ngabayen uyen? ngadorianak

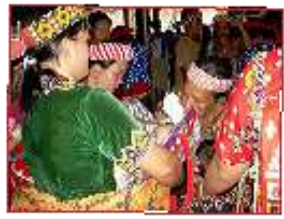

Figure 8. The use of space in ngabayen uyen ngadananak activities

Settlement characteristics

This theme consists of 4 information units, namely uniformity in the settlement pattern as the pemung tawai, and pegayan kuaq slogans which causes it to be close together, form, and physical elements. The characteristics are determined by the physical and non-physical elements that constitute a certain pattern. It is influenced by the philosophies of uyen tiga nangaliku panaq and uyen tiga nangaliku kelunan.

Based on the uyen tiga nangaliku panaq philosophy, fellow Dayak Kenyah tribes need to unite and maintain peace, in order to instill harmony. This recommendation is in the form of the Pemung tawai slogan which means one mind and one goal. However, its motto is to maintain unity among the Dayak Kenyah tribe, which in ancient times, experienced disputes on a regular 
basis, it therefore led to an agreement to build a lamin adat as a symbol of unity and peace. This also serves as a reference for each clan to build a personal stage settlement (amin lu'ung) that aligns with the lamin adat and its decorative ornaments as shown in figures 9 and 10 .

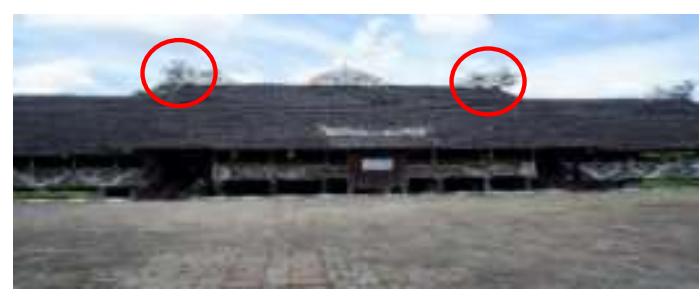

Figure 9. Lamin adat with a roof decoration in the form of a hornbill motif

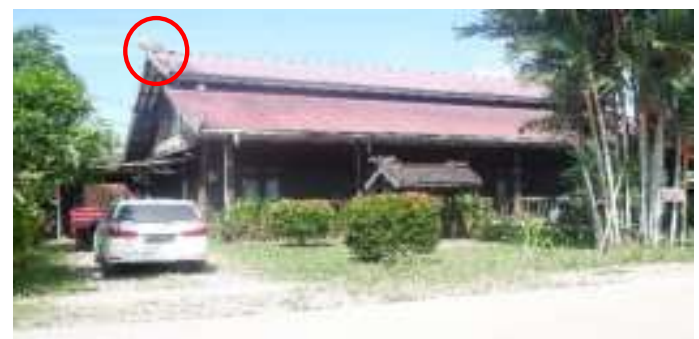

Figure 10. Amin lu'ung (private house) in the form of a stage with a roof decoration in the form of a hornbill motif as a symbol of leader and peace

The suggestion to live in unity with fellow Dayak Kenyah tribes is contained in the uyen tiga nangaliku panaq philosophy which regulates interactions between members. In addition to the Pemung tawai slogan, this suggestion serves as a societal guide as manifested in the Kuaq Pegayan motto, which means mutual assistance or help. Subsequently, mutual assistance among fellow tribes prioritizes quick response to help families and relatives in distress. Therefore, the relatives' settlements are located close by as shown in figure 11.

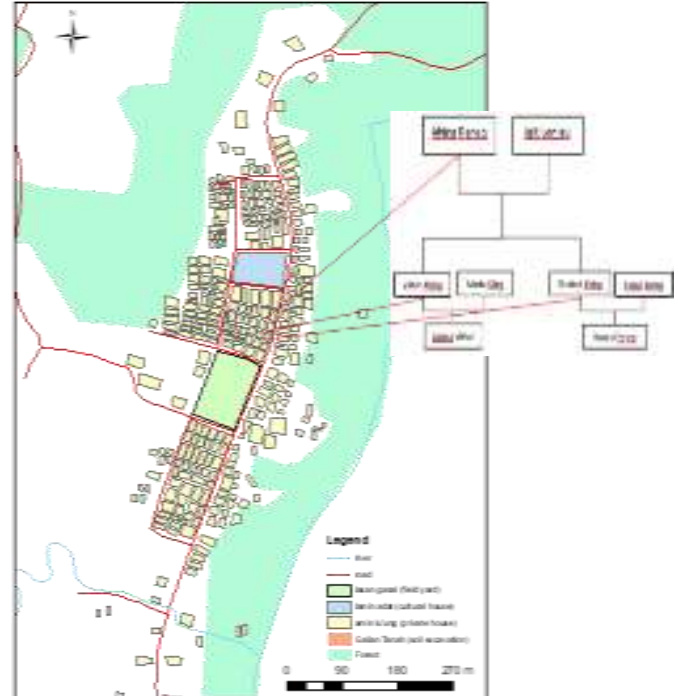

Figure 11. Settlement based on kinship

The settlement of the Dayak Kenyah community consists of 2 types, namely amin lu'ung which functions as a residence and lamin adat (umaq dadoq) a means of cultural activity. In the past, the umaq dadoq functioned as a communal house containing 5 to 12 family heads. However, with a consensus to create unity among the Dayak Kenyah tribes, the lamin adat serves as a symbol of unity between the existing clans as well as the center of cultural activity. It is in accordance with the pemung tawai slogan which originated from the uyen tiga nangaliku panaq philosophy, namely respecting fellow tribes. The amin lu'ung connection with a lamin adat as the center of cultural activity forms a distinctive settlement pattern as shown in figure 12 .

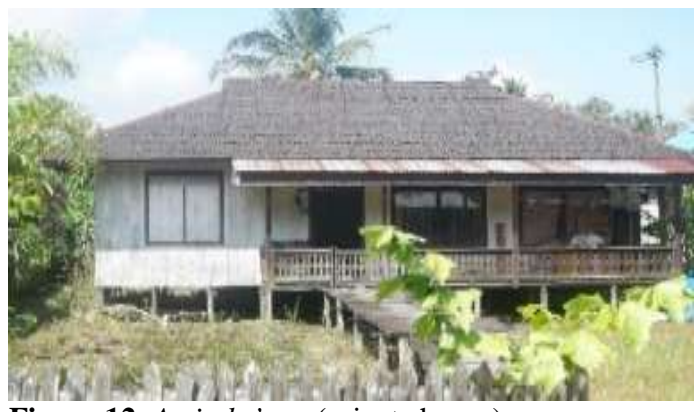

Figure 12. Amin lu'ung (private house)

Traditional settlement is built with various physical elements, based on field observations, shown in figure 13. 


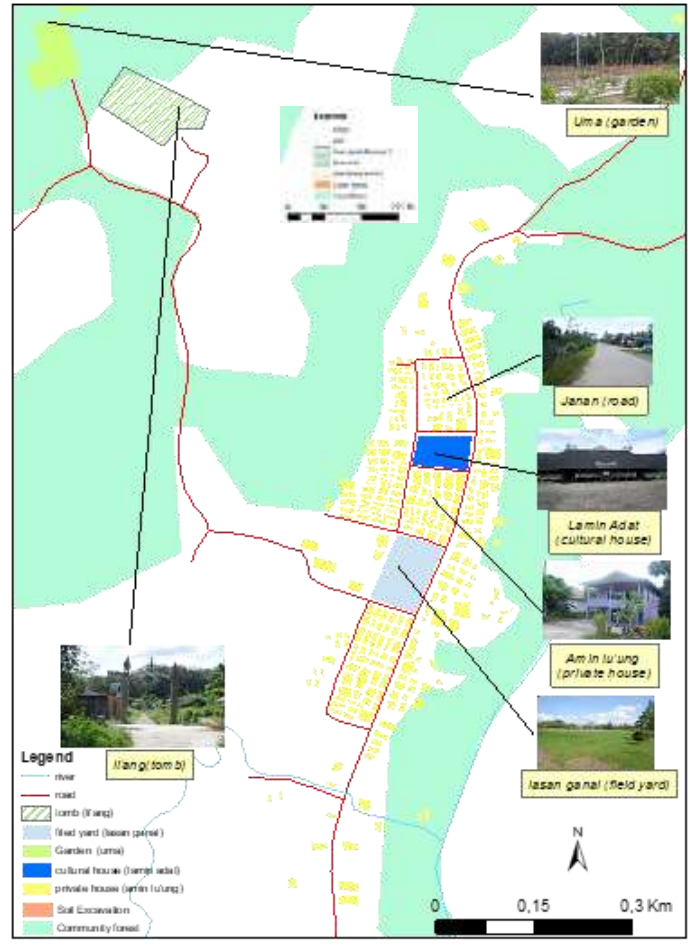

Figure 13. Physical elements in forming a settlement

Based on figure 13, some physical elements of settlement formation are explained as follows, lamin adat located in the south is a center of cultural activity and a unity symbol among the Dayak Kenyah tribe. Amin lu'ung is a settlement in the form of a stage. The east orientation signifies the houses of noble descents while the west depicts the common people. Janan (road) is an extremely important public space connecting every element and socio-cultural activities. Lasan ganal (field) is an open space where residents gather and carry out cultural activities. Li'ang (tomb) located in the east of lepoq is the final resting place of the dead. It is oriented towards the west as a sign of sunset and as a manifestation of the deceased departure. The laying of the 4 corners of the compass is carried out by elders considered to have supernatural abilities.

\section{Culture in processing natural resources}

This theme consists of 3 (three) information units, namely gilir balik Bahuma (farming), the culture of harvesting honey, and logs utilization. Community activities associated with processing natural resources affects their living concept. This culture is influenced by the uyen tiga nangaliku kelunan philosophy which regulates the interaction between the Dayak Kenyah tribe and the surrounding environment. Some sociocultural activities in processing natural resources are described as follows

Bahuma is one of the activities carried out to meet daily needs. The rotational method (gilir balik) is adopted with the concept of saving land, namely farming activities are only rotated in a cycle of 2 to 5 years. Therefore, supposing the land is infertile, the farmers are not forced to work on the farm. This system emphasizes on saving land use and preserving the environment in accordance with the uyen tiga nangaliku kelunan philosophy. This activity uses settlement spaces as shown in figure 5 .

Local wisdom is involved in the process of harvesting honey and logs utilization. The honey tree is a type of plant that lives in the forest around the Budaya Pampang Village. It serves as a place for bees to nest. This tree has physiological characteristics, namely, taproots and a large trunk size and is suitably used as a material for building houses or furniture. It has a longer life-cycle than other plant types and serves as nesting place for honey bees. The Pampang people have a habit of harvesting honey using the root burning ritual. In executing these activities, people are prohibited from cutting and using the stems to build houses because they believe that large and towering honey trees have guards. Likewise, the use of logs as building materials for houses is also prohibited. They are only used to make boats because according to ancient beliefs it is an aquatic substance that need not be used on land. However, assuming properly examined, maintaining the availability of logs in the Budaya Pampang Village is a form of local wisdom.

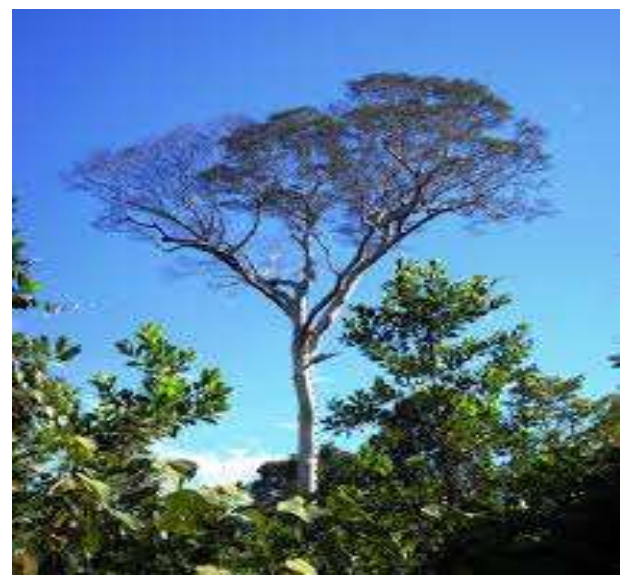

Figure 14. A honey tree that is forbidden to cut down for building materials 
Concepts and theories

Based on the explanation of the information units in the 5 empirical themes, 2 concepts and a local theory are formed as shown in the following figure 15 .

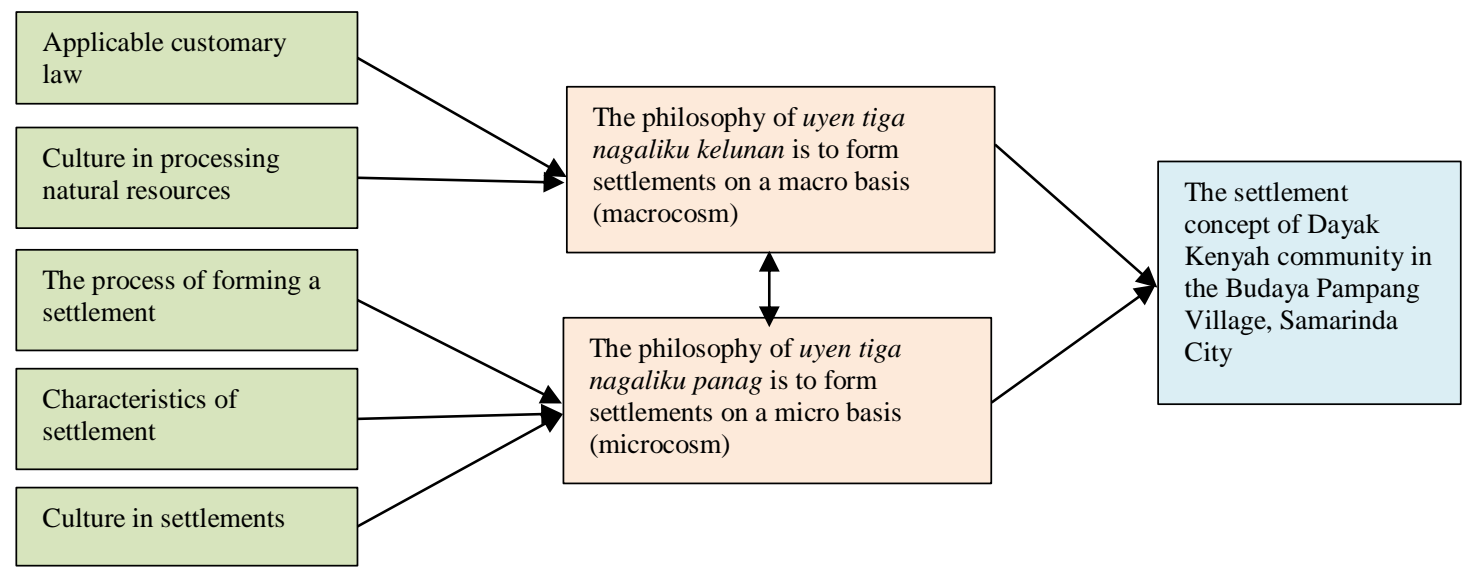

Figure 15. The flow of theory formation

Based on figure 15 , it is a known fact that 2 (two) of the concepts result from the deepening of 5 (five) empirical themes, namely the uyen tiga nangaliku kelunan and uyen tiga nangaliku panaq philisopies forming settlement on a macro and micro basis respectively. The macro settlement is influenced by 2 empirical themes, namely applicable customary law and the cultural activities involved in processing natural resources. It is a broad living space formed from the relationships between the Dayak Kenyah and other tribes, with their creator including the natural surroundings.

The uyen tiga nangaliku kelunan philosophy is the concept of a shared house that regulates the relationship between the Dayak Kenyah and other tribes, their creator, and the natural environment therefore it is in line with the concept of macro space. The advice contained in the philosophy of uyen tiga nangaliku kelunan plays a role in the formation of settlement pattern, including the prohibition of building housing around u'ung (waterfalls), the motto of pebeka udip (living in unity), the restriction placed on cutting down honey trees and logs, and the application of rotation practices (gilir balik) in the bahuma inspires residents to save land for farming activities and residential areas.

Furthermore, the concept of the uyen tiga nangaliku panaq philosophy forms settlement space on a micro basis. Its shape is influenced by 3 interrelated empirical themes, namely the process of settlement formation, culture, and its characteristics. The micro space, in this case, is formed from the socio-cultural activities of the Dayak Kenyah community on a smaller scale. The uyen tiga nangaliku panaq philosophy is part of a shared house (uyen tiga) concept, which regulates relations between fellow Dayak Kenyah tribes in the Budaya Pampang Village. Therefore, this is in line with the definition of micro space. Some of the advice or suggestions of the uyen tiga nangaliku panaq philosophy that affects settlement patterns on a micro basis include the mottos of pemung tawai (one mind, one goal), and pegayan kuaq, shifting livelihoods and cultural space within a settlement.

The uyen tiga nangaliku kelunan and uyen tiga nangaliku panaq philosophies are part of a big concept, namely the uyen tiga, which means shared house. The relationship between fellow residents, which is a form of mutual respect realized from living together in the Uyen tiga, is manifested in advice, slogans, and socio-cultural activities such as traditional rituals. Therefore, it resulted in a local theory, namely the concept of the Dayak Kenyah Tribe Community Settlement in the Budaya Pampang Village, which was proposed based on the values contained in the Uyen tiga philosophy, as shown in figure 16. 


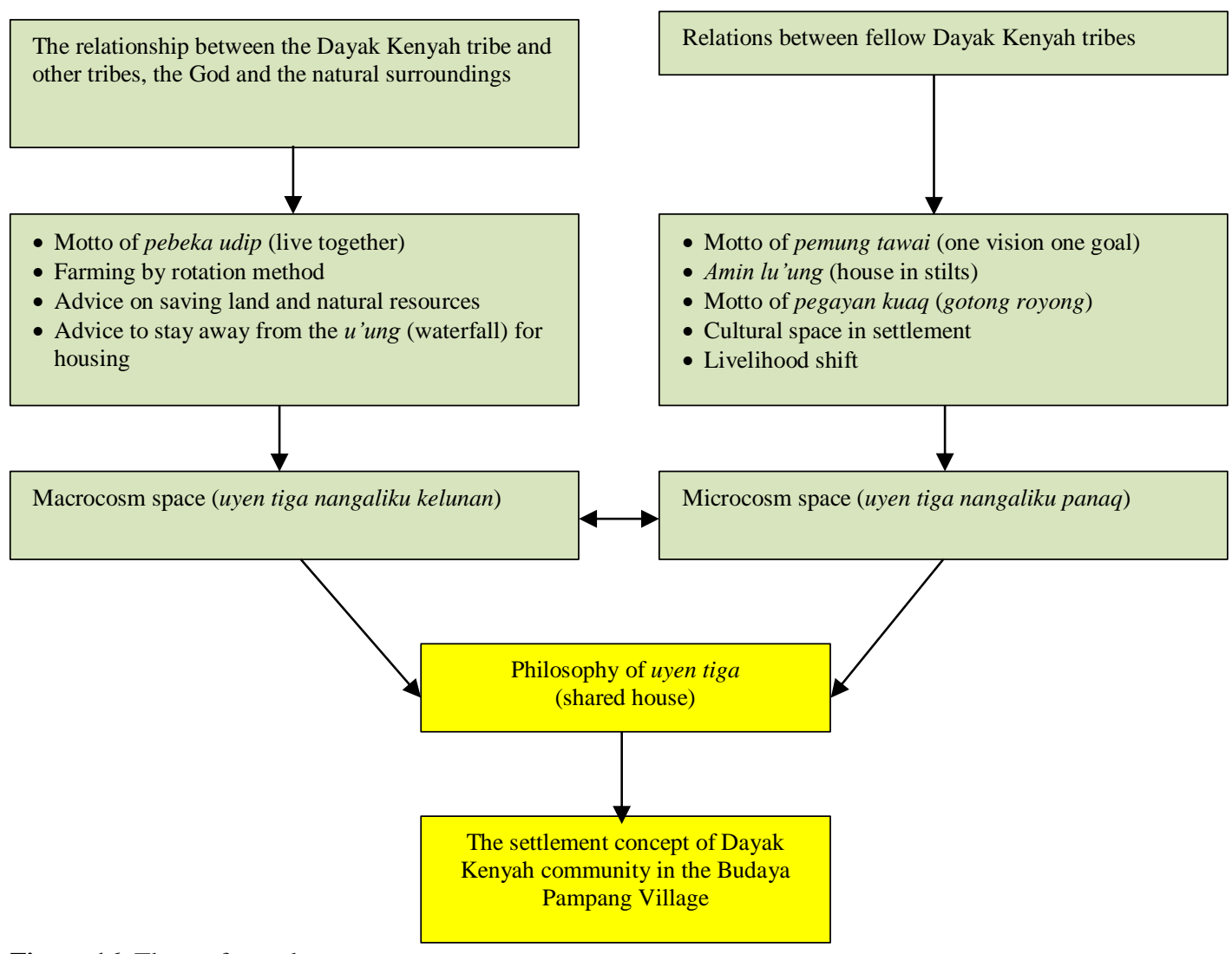

Figure 16. Theory formed

Figure 16 showed that the Uyen tiga philosophy means a shared house with diverse values associated with local wisdom. The values that form macro and micro spaces aim to create peace, and harmony, among the residents (entities). This is in line with the studies carried out by Matondang (2021) and Siti Rukayah et al. (2018) which stated that local wisdom in spatial settlement planning aims to bring harmony in environmental, social, economic, and religious aspects. The brotherhood value between members (pemung tawai) and those from other tribes (pebeka udip) adhered to by the community in settlement (lepoq) is the basis for maintaining harmony. This is consistent with the research carried out by Aghsari, Wekke, and Abbas (2018), which stated that the values of brotherhood and tolerance are the binding harmony of society in the midst of ethnic, religious, and cultural differences.

\section{Conclusion}

The local wisdom of the Dayak Kenyah community in the Budaya Pampang Village is reflected in the traditional settlement (lepoq) and their environment, which is influenced by the uyen tiga philosophy. Consequently, it consists of the uyen tiga nangaliku kelunan (macrocosm) and the uyen tiga nangaliku panaq (microcosm) philosophies. The uyen tiga nangaliku kelunan is a form of residential spaces on a wider scale (macro) because there is good interaction between the Dayak Kenyah and other ethnic groups, the Creator, and the Environment.

Advices and slogans that form macro settlement in the uyen tiga nangaliku kelunan philosophy, namely staying away from u'ung (waterfalls), the motto of pebeka udip (living together), rotational (gilir balik) farming (bahuma) practices, save land, and the processing of natural resources.

The uyen tiga nangaliku panaq philosophy is a form of settlement spaces on a narrower scale (micro) due to interactions between fellow Dayak 
Kenyah tribes. This micro space is reflected in the pemung tawai slogan (one mind, one goal), the motto of pegayan kuaq (cooperation), cultural activities in the settlement, shifts in sources of livelihoods, and shelter in the form of stages.

These findings are used as input in the preparation of spatial planning documents in East Kalimantan Province. In addition, their application and spatial planning documents are more participatory and sustainable by taking into account the local wisdom of the local community.

\section{References}

Adiputra, IGN Tri, Sudaryono, Djoko Wiyono, and Ahmad Sarwadi. 2016. 'Konsep HuluTeben Pada Permukiman Tradisional Bali Pegunungan/Bali Aga Di Desa Adat Bayung GedeKecamatan Kintamani Kabupaten Bangli, Bali'. Forum Teknik 37 (1): 14-31. https://jurnal.ugm.ac.id/mft/article/view/1153 4/8600.

Aghsari, Diah, Ismail Suardi Wekke, and Nurlaelah Abbas. 2018. 'Harmony of Coastal Community Regarding Its Ethnic Religion and Cultural Diversity'. IOP Conference Series: Earth and Environmental Science 156 (May): 012034. https://doi.org/10.1088/17551315/156/1/012034.

Agustian, Endy, Rini Rachmawati, R. Rijanta, and Agus Joko Pitoyo. 2020. 'Multi-Ethnic Settlement Concept in Denpasar City, Bali, Indonesia'. Journal of Physics: Conference Series $\quad 1655 \quad$ (1): 012132. https://doi.org/10.1088/17426596/1655/1/012132.

Ari, Ismu Rini Dwi, and Antariksa. 2005. 'Studi Karakteristik Pola Permukiman Di Kecamatan Labang, Madura'. Jurnal ASPI (Asosiasi Sekolah Perencana Indonesia) 4 (2): 78-93.

Burhan, Issana Meria, Antariksa, and Christia Meidiana. 2008. 'Pola Tata Ruang Permukiman Tradisional Gampong Lubuk Sukon, Kabupaten Aceh Besar'. Arsitektur EJournal $\quad 1 \quad$ (3): $172-89$. http://antariksa.lecture.ub.ac.id/2008/11/.

Coomans, Michael. 1987. Manusia Daya: Dahulu, Sekarang, Masa Depan. Jakarta: Gramedia Pustaka Utama.

Dwijendra, Ngakan Ketut Acwin. 2008. Arsitektur Rumah Tradisional Bali:
Berdasarkan Asta Kosala-Kosali. Bali: Udayana University Press.

Harefa, Anugerah Septiaman. 2019. 'Pelestarian Desa Hilinawalo Mazino Di Kepulauan Nias Sebagai Destinasi Wisata'. ARTEKS : Jurnal Teknik Arsitektur 4 (1): 57-62. https://doi.org/10.30822/arteks.v4i1.79.

Hermanto, Heri, Achmad Djunaedi, and Sudaryono. 2014. 'Konsep Ruang SakralProfan Pada Tata Permukiman Di Dataran Tinggi Dieng'. Jurnal PPKM II 1 (2): 102-14. Kahija, YF La. 2017. Penelitian Fenomenologis. Yogyakarta: Kanisius.

Kumurur, Veronica A, and Setia Damayanti. 2009. 'Pola Perumahan Dan Pemukiman Desa Tenganan Bali'. Jurnal Sabua 1 (1): 1-7. https://ejournal.unsrat.ac.id/index.php/SABU A/article/view/246.

Matondang, Saiful Anwar. 2021. 'Sustainability Effort of Traditional "Lubuk Larangan" Forbidden Deep Pool Stream'. WSEAS TRANSACTIONS ON ENVIRONMENT AND DEVELOPMENT 17 (February): 138-44. https://doi.org/10.37394/232015.2021.17.14.

Mazza, Angelo, and Antonio Punzo. 2016. 'Spatial Attraction in Migrants' Settlement Patterns in the City of Catania'. Demographic Research $\quad 35 \quad$ (July): 117-38. https://doi.org/10.4054/DemRes.2016.35.5.

Nilasari, Poppy Firtatwentyna, Ronald Hasudungan Irianto Sitindjak, and Laksmi Kusuma Wardani. 2019. 'Tenganan Indigenous Village as a Cultural Historical Tourism Destination in Bali Island, Indonesia'. African Journal of Hospitality, Tourism and Leisure 2019 (Special Issue): 17.

Pahude, Mansur S., Sudaryono, and Didik Kristiadi. 2017. 'Konsep Ruang Permukiman Tradisional Sebagai Basis Wisata Di Desa Sabang Kabupaten Tolitoli'. In Strategi Pengelolaan Sumber Daya Daerah Dalam Menciptakan Good Governance. Jember: Program Pascasarjana Fakultas Ekonomi dan Bisnis Universitas Jember.

Pergitawati, Ririn Prasetya, Antariksa, and Abraham Muhammad Ridjal. 2014. 'Perubahan Pola Ruang Dalam Rumah Lamin Adat Dayak Kenyah Akibat Pengaruh 
Modernisasi Di Desa Pampang, Samarinda'. Arsitektur E-Journal 7 (2): 90-101.

Rapoport, Amos. 1969. House, Form, and Culture. New York: Prentice Hall.

Sasongko, Ibnu. 2005. 'Pembentukan Struktur Ruang Permukiman Berbasis Budaya'. DIMENSI (Journal of Architecture and Built Environment) $\quad 33 \quad$ (1): $1-8$. https://dimensi.petra.ac.id/index.php/ars/artic le/view/16270.

Sastrosasmito, Sudaryono. 2020. 'Arsitektur Sebagai Realitas Kemanusiaan (Dari Keseharian Sampai Kesadaran Transendental)'. ARTEKS: Jurnal Teknik Arsitektur 5 (2): 141-42. https://doi.org/10.30822/arteks.v5i2.531.

Singarimbun, Masri. 1991. 'Beberapa Aspek Kehidupan Masyarakat Dayak'. Humaniora, no. 3.

Siti Rukayah, R., Dhanang Respati Puguh, Endang Sri Susilo, and Mohammad Sahid Indraswara. 2018. 'Local Wisdom of The Native Settlement as A Main Gate in The Northern Axis of Javanese City Center In Semarang'. IOP Conference Series: Earth and Environmental Science 152 (May): 012032. https://doi.org/10.1088/17551315/152/1/012032.

Sugiyono. 2019. Metode Penelitian Kuatintatif, Kualitatif Dan R\&D. Alfabeta. 2nd ed. Bandung: Alfabeta. https://doi.org/2008.

Sulisthio, Ivan, and Esti Asih Nurdiah. 2013. 'Fasilitas Ecomuseum Suku Dayak Kenyah Desa Pampang Di Samarinda'. JURNAL EDIIMENSI ARSITEKTUR 1 (2): 225-32. https://publication.petra.ac.id/index.php/tekni k-arsitektur/article/view/1250/0.

Tuan, Yi-Fu. 1997. Space and Place: The Perspective of Experience. United States: University of Minnesota Press.

Wibawa, I. Putu Sastra, F. X.Adji Samekto, and I. Putu Gelgel. 2019. 'Determination of the Sacred Space Uluwatu Temple with the Gis Approach'. International Journal of Scientific and Technology Research 8 (11): 954-58.

Wicaksono, Bambang, and Susilo Kusdiwanggo. 2016. 'Modus Bermukim Masyarakat Riparian Sungai Musi Palembang'. In The Lost World: Historical Continuity for Sustainable Future, 11-20. Yogyakarta: Universitas Atma Jaya Yogyakarta.

Yusupova, Guzel. 2018. 'Making Ethnic Boundaries in the Society of Religious Renaissance: Islam and Everyday Ethnicity in Post-Soviet Tatarstan'. National Identities 20 (4):

345-60. https://doi.org/10.1080/14608944.2016.1265 493.

\section{Author(s) contribution}

Puput Wahyu Budiman contributed to the research concepts preparation, methodologies, investigations, data analysis, visualization, articles drafting and revisions.

Sudaryono contribute to the research concepts preparation and literature reviews, data analysis, of article drafts preparation and validation. 
ARTEKS : Jurnal Teknik Arsitektur, Volume 6 Issue 3, December 2021

pISSN 2541-0598; eISSN 2541-1217 